Collection: RegioResources21 - "Spatial information and participation of socio-ecological systems: experiences, tools and lessons learned for land-use planning"

Guest Editors: Daniele La Rosa, Carsten Lorz, Hannes Jochen König, Christine Fürst

\section{Linking biomass production in short rotation coppice with soil protection and nature conservation}

\author{
Rainer Petzold ${ }^{(1)}$, David Butler-Manning ${ }^{(2)}$, Norbert Feldwisch ${ }^{(3)}$, \\ Thomas Glaser ${ }^{(4)}$, Peter A Schmidt ${ }^{(5)}$, Maik Denner ${ }^{(6)}$, Karl-Heinz \\ Feger $^{(7)}$
}

Biomass from short rotation coppice (SRC) plantations has attracted widespread attention as a component of new sustainable energy concepts. Nevertheless, as yet the surface area of SRC plantations in Europe is relatively low compared to other biomass producing land-use systems. This is somewhat incomprehensible because it has been shown that SRC systems also offer distinct ecological benefits. Therefore, greater consideration of the related ecosystem services should be incorporated into land-use planning processes. Presented in this study is a conceptual framework for the integration of soil protection and nature conservation into the spatial prioritization of areas suitable for SRC. This approach includes the development of a site-specific yield model and the identification and classification of criteria and indicators for both soil protection and nature conservation. The basic concept for planning procedures was established and tested for the State of Saxony (Germany). Existing constraints were identified, and could be attributed mainly to the availability of adequate information at different spatial scales. The regional-scale study emphasized the considerable biomass potential of SRC and the related synergy effects for soil protection and nature conservation. Future work should focus on the local (district, farm) and catchment scale and attempt to integrate additional aspects such as hydrological ecosystem services and carbon sequestration.

Keywords: Short Rotation Coppice, Yield Estimation, Soil Protection, Nature Conservation, Land Use Planning

\begin{abstract}
Introduction
A goal of the European Union states that up to the year 2020 the contribution of renewable sources of energy to total primary energy consumption should increase to a proportion of $20 \%$ (EC 2009). Plantations of fast growing tree species with short rotations and subject to coppice management (SRC), grown on arable land for the purposes of heat or combined heat and power production are seen as a very effective means to achieve increased environmental benefits. In comparison to other biomass production systems, such as oil seed rape for oil production or maize for gasification, SRC is characterized by a positive greenhouse gas balance (Hellebrand et al. 2010) and therefore low $\mathrm{CO}_{2}$ emission reduction costs (SABAP 2007). Furthermore, SRC has positive effects on soil ecology (Makeschin 1994) and water quality (Schmidt-Walter \& Lamersdorf 2012), and increased biodiversity (Rowe et al. 2011, Glaser \& Schmidt 2010). The aforementioned benefits provided to society
\end{abstract}

by SRC may be summarized under the heading of ecosystem services (Daily et al. 1997). It is also suggested from an economic perspective that lignocellulose supply systems like SRC should be stimulated in order to develop the high inherent potential for the production of bioenergy within Europe (Berndes \& Hansson 2007, deWit \& Faaij 2010). At present, however, the area of SRC in Europe with around 50000 ha remains rather low in comparison with other biomass systems, e.g., maize silage production for biogas on 700000 ha in Europe (Don et al. 2012). There are many possible reasons for this, for example:

- low availability of arable land for the establishment of SRC systems due to competition with food production;

- biased market situation brought about by counterproductive subsidies in the agricul2007, 2010, Berndes \& Hansson 2007);

- few best practice examples sufficiently highlighting the benefits of SRC (Hofftural biomass production sector (SABAP
(1) Public Enterprise Sachsenforst, Competence Center for Wood and Forestry, Bonnewitzer Str. 34, 01769 Pirna (Germany); (2) TU Dresden, Institute of International Forestry and Forest Products, Pienner Str. 19, 01737 Tharandt (Germany); (3) Consulting Engineers, Ingenieurbüro Feldwisch, Karl-Phillip-Str. 1, 51429 Bergisch Gladbach (Germany); (4) Office for Nature Conservation and Sustainable Land Use, Rittergut 16, 01909 Großhartau (Germany); (5) TU Dresden, Institute of General Ecology and Environmental Protection, Pienner Str. 7, 01737 Tharandt (Germany); (6) Saxon State Agency for Environment, Agriculture and Geology, Postfach 540137, 01311 Dresden (Germany); (7) TU Dresden, Institute of Soil Science and Site Ecology, Pienner Str. , 01737 Tharandt (Germany)

\section{(a) Rainer Petzold \\ (Rainer.Petzold@smul.sachsen.de)}

Received: Oct 31, 2013 - Accepted: Nov 14, 2013

Citation: Petzold R, Butler-Manning D, Feldwisch N, Glaser T, Schmidt PA, Denner $\mathrm{M}$, Feger K-H, 2014. Linking biomass production in short rotation coppice with soil protection and nature conservation. iForest 7: 353-362 [online 2014-05-19] URL: http://www.sisef.it/iforest/contents/? id=ifor 1 168-007

Communicated by: Marco Borghetti

mann \& Weih 2005);

- prejudices on the part of environmentalists and the public against land-use alterations (Pretzsch \& Skodawessely 2010);

- legislative restrictions placed on landowners;

- reduction of landowners' opportunities to adjust agricultural production in reaction to short-term market developments as SRC is a long term commitment;

- a high proportion of arable land is merely leased and not owned;

- no adequate consideration of SRC in landuse planning procedures to date.

Some of the obstacles mentioned may be reduced only through modifications to the political framework conditions. However, existing knowledge with regard to SRC must also be better communicated, in order to promote broader acceptance amongst the various stakeholder groups (Skodawessely et al. 2008).

The authors hypothesized that an integrated ("holistic") planning approach would be useful to develop greater practical evidence of SRC. In a first step, the potential effects of biomass production in SRC with regard to nature conservation and soil protection should be recognized as being important 
Tab. 1 - Main geographic regions of Saxony, and the corresponding climate and soil characteristics.

\begin{tabular}{lcccl}
\hline $\begin{array}{l}\text { Geographic } \\
\text { region }\end{array}$ & $\begin{array}{c}\text { Altitude } \\
{[\mathbf{m} \text { asl] }}\end{array}$ & $\begin{array}{c}\text { Mean annual } \\
\text { air temperature } \\
{\left[{ }^{\circ} \mathbf{C}\right]}\end{array}$ & $\begin{array}{c}\text { Mean annual } \\
\text { precipitation } \\
{[\mathbf{m m}]}\end{array}$ & $\begin{array}{l}\text { Predominant } \\
\text { soil type }\end{array}$ \\
\hline Lowlands & $80-200$ & $8.0-9.0$ & $550-650$ & Sandy Cambisols \\
Hilly region & $100-400$ & $7.5-9.0$ & $480-800$ & Luvisols \\
Low mountain range & $400-1215$ & $4.0-8.0$ & $700->1000$ & Sceletic Cambisols \\
\hline
\end{tabular}

components of ecosystem services (Daily et al. 1997). Therefore, existing synergy effects should be depicted and assessed, e.g., within planning processes or formulation of subsidy programs, as should potential trade-offs.

The aim of the study was to develop a conceptual framework for the planning of SRC at a regional scale in the Federal State of Saxony (Germany). This included: (1) a conceptual model to predict SRC biomass production on the basis of available soil and climate data; (2) defining priority and exclusion areas in relation to soil protection; (3) defining priority and exclusion areas in relation to species and habitat protection and legally protected areas; (4) application of the results within a GIS environment.

\section{Materials and methods}

\section{Study area}

The Federal State of Saxony is located in eastern Germany. It covers a total area of 18 $415 \mathrm{~km}^{2}$. The state can be classified into three main geographical regions along a site gradient running from north to south, namely the lowlands, the hilly region and the low mountain range region (Tab. 1).

Agriculture is the predominant land use in the Saxony lowlands, particularly in the more fertile areas located at the transition to the hilly loess region. There are also large areas to the north and northeast of the lowlands that have been affected by lignite open pit mining and subsequent reclamation. Forest cover amounts to $27 \%$ of the lowland surface area.

The hilly region of Saxony is a typically agrarian landscape with large open fields featuring only very few structural elements such as trees and shrubs. Forests cover only $12 \%$ of the state's hilly region. Due to their fine texture and the intensive farming, the soils are often prone to erosion by wind and water.

Forest cover in the low mountain range (Ore Mountains) is $42 \%$ of the surface area (Schwanecke \& Kopp 1996). Arable land uses still predominate in the lower parts, but with increasing altitude grasslands become dominant and in the upper parts forest. Most of Saxony's rivers spring from the Ore Mountains, making the region extraordinarily important for public water supply.

\section{Estimation of the site-specific} production of biomass in $S R C$

It has been shown that under the prevailing

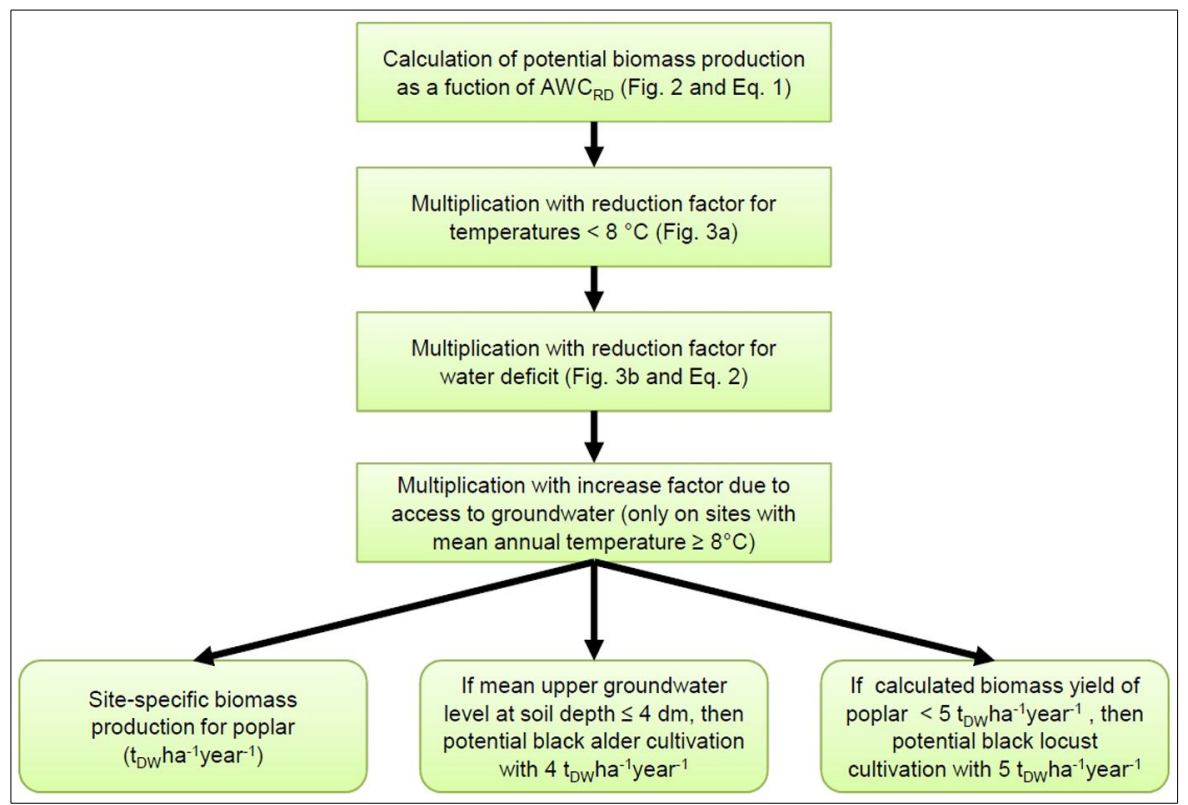

Fig. 1 - Flow chart for the calculation of site-specific production of biomass in SRC. site conditions in Germany, biomass production by hybrid poplars exceeds that of willow clones in most cases (Hoffmann \& Weih 2005 ). The first step in this study was to employ the empirical yield model developed by Ali (2009) to predict the production potential of SRC hybrid poplar on arable land in Saxony. The model includes climate variables (mean precipitation and temperature values during the growing season) and the plant available water capacity $\left(A W C_{\mathrm{RD}}\right)$ depending on texture and rooting depth. The German site quality index for arable soils ("Ackerwertzahl" - AZ) was also implemented. The AZ may vary between 7 (very poor) and 100 (very good). In the case of sites with $A Z=50$ the harvested yield of the reference crop wheat is roughly $50 \%$ of that of sites with $A Z=100$ (for further details on soil parameters, see Ad-hoc-AG Boden 2005). However, digital data of $A Z$ values is currently not always available at a high spatial resolution. In the case of Saxony, digital AZ data exists only in the form of an aggregated value at the community administration level (LfULG 2011). This limits the spatial resolution of the modeling results. One of the simulation scenarios developed by Ali (2009) was taken as a basis for further downscaling (clone: Populus nigra $x$ P. maximowiczii, cv. Max; planting density: 10000 cuttings $\mathrm{ha}^{-1}$; biomass production: average annual growth in $t_{\mathrm{Dw}} \mathrm{ha}^{-1}$ year $^{-1}$ at the age of 9 years). It is generally accepted, that on former agricultural land the crucial factor for productivity of SRC is water availability (Röhle et al. 2008). Therefore, only soil physical and climatological site indicators were used in the following procedure for downscaling (see scheme in Fig. 1).

Due to the strong nonlinear correlation between potential biomass production $B P_{\mathrm{pot}}$ and $A W C_{\mathrm{RD}}$ (Fig. 2), the potential biomass production could be expressed as follows (eqn. 1):

$$
B P_{p o t}=f\left(A W C_{R D}\right)
$$

This relationship was used to downscale to a higher spatial resolution on the basis of the soil map for Saxony 1:200 000 (LfULG 2007).

In a second step, we implemented reduction factors $(R F)$ ranging from 0 to 1 for low temperature $R F_{\mathrm{T}}$ and drought $R F_{\mathrm{D}}$, respectively. Employing this ecophysiologically-oriented approach, the lower boundaries for the empirical growth model were defined. This accounted for the existing limits of site gradients in Saxony. The low temperature response followed certain assumptions:

- no biomass production at a mean annual temperature $<5{ }^{\circ} \mathrm{C}$;

- favorable conditions for biomass production from a mean annual temperature of 6.5 ${ }^{\circ} \mathrm{C}$ (here $75 \%$ of the optimal biomass pro- 
duction potential); and

- no limitations at mean annual temperatures $\geq 8{ }^{\circ} \mathrm{C}$

Petzold et al. (2011) showed that as the growing season advances, the transpiration of poplar plantations on sites without groundwater access in the drier regions of northern Saxony is controlled by a reduction in water availability (Lamersdorf et al. 2010). Based on long-term average climatological conditions we assumed that by the end of June, halfway through the growing season, $\approx 50 \%$ of the biomass production is achieved. Afterwards growth may be severely limited by soil water shortage. Consequently, a drought index $I_{\mathrm{D}}$ was defined as follows (eqn. 2):

$$
I_{D}=0.5 \cdot A W C_{R D}+C W B_{\text {Summer }}
$$

where $A W C_{\mathrm{RD}}[\mathrm{mm}]$ is the available water capacity at the effective rooting depth and $C W B_{\text {Summer }}[\mathrm{mm}]$ is the accumulated climatic water balance during the period April-September. $C W B_{\text {Summer }}$ was calculated as the difference between precipitation and potential evapotranspiration over grass (FAO). All of the climate data (period 1991-2005) originates from SMUL (2008).

Smoothing functions for temperature and drought response were adjusted according to Fig. 3.

Growth conditions can improve significantly on warm sites where tree roots have access to groundwater, even in the event of a low climatic water balance. By contrast, sites with long periods of water logging and cold sites are not suitable for poplar cultivation. These specific site conditions were accounted for by incorporating the factor groundwater $F_{\mathrm{GW}}$ as follows:

- $F_{\mathrm{GW}}=0$; exclusion of poplar SRC at mean upper groundwater level (MUGL) at soil depth $\leq 4 \mathrm{dm}$ (alternative: Alnus glutinosa - see below);

- $F_{\mathrm{GW}}=1.25$; biomass production at mean annual temperatures $\geq 8{ }^{\circ} \mathrm{C}$ and $4 \mathrm{dm}<$ MUGL $\leq 10 \mathrm{dm}$ (if temperature $<8{ }^{\circ} \mathrm{C}$ then $F_{\mathrm{GW}}=1$ );

- $F_{\mathrm{GW}}=1.1$; biomass production at mean annual temperatures $\geq 8{ }^{\circ} \mathrm{C}$ and $20 \mathrm{dm}>$ MUGL > $10 \mathrm{dm}$ (if temperature $<8{ }^{\circ} \mathrm{C}$ then $F_{\mathrm{GW}}=1$ );

Information pertaining to this site property was derived from soil profile descriptions included in the digital soil map (LfULG 2007).

Finally, the complete site-specific biomass production $B P$ for poplar was calculated as follows (eqn. 3):

$$
B P=\left(0.5 \cdot B P_{p o t}+0.5 \cdot B P_{p o t} \cdot R F_{D} \cdot R F_{T}\right) \cdot F_{G W}
$$

Alder (Alnus glutinosa) is recommended as an alternative species for SRC cultivation on very wet sites with MUGL $\leq 4 \mathrm{dm}$ below the surface. This tree species is characterized by

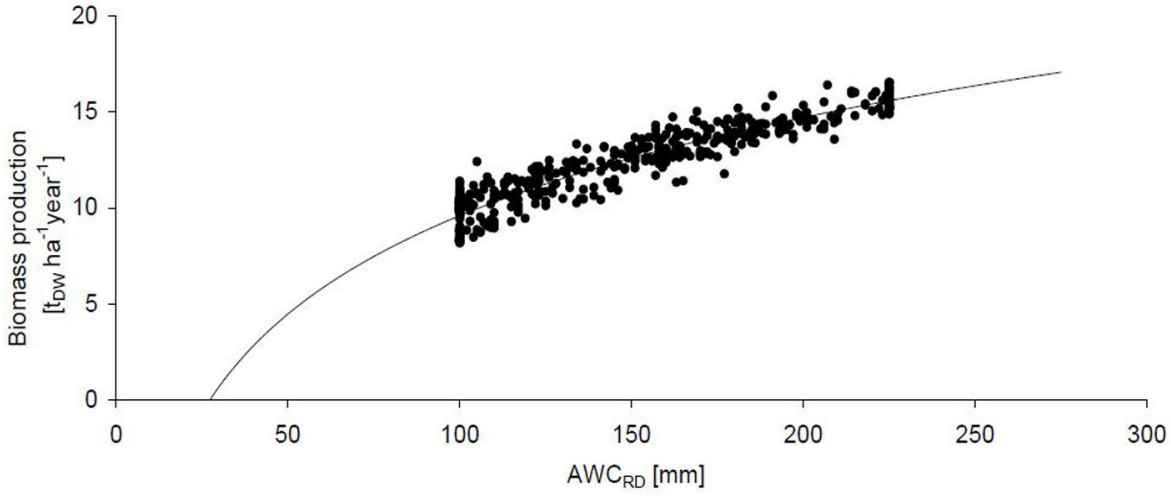

Fig. 2 - Relationship between $\mathrm{AWC}_{\mathrm{RD}}$ and biomass production (biomass $=7.384 \cdot \ln$ $\left.\left(A W C_{R D}\right)-24.4 ; R^{2}=0.89, \mathrm{p}<0.001\right)$. The minimum for biomass production was fixed at $\mathrm{AWC}_{\mathrm{RD}}=60 \mathrm{~mm}$ (data source: Ali 2009) .

a growth culmination at a later age and so grows slower than poplar (Lockow 1995). An overall biomass production of $4 t_{D w} h^{-1}$ year ${ }^{-1}$ was assumed for all wet sites.

The cultivation and production of poplar biomass on warm and dry sites is very uncertain and can drop below $5 \mathrm{t}_{\mathrm{DW}} \mathrm{ha}^{-1}$ year $^{-1}$, or possibly even fail completely. Under such conditions, black locust (Robinia pseudo-

acacia) provides an alternative, even though the forecast yields may be low. Black locust biomass production may range from $3.3 \mathrm{t}_{\mathrm{DW}}$ ha $^{-1}$ year $^{-1}$ (Böhm et al. 2009) on reclaimed sites formerly used for surface mining of lignite in southern Brandenburg, and up to 5.5 $t_{D W} h^{-1} a^{-1}$ in northeast Brandenburg (Peters et al. 2007). For dry sites characterized by mean annual temperatures $>8{ }^{\circ} \mathrm{C}$ and a fore-
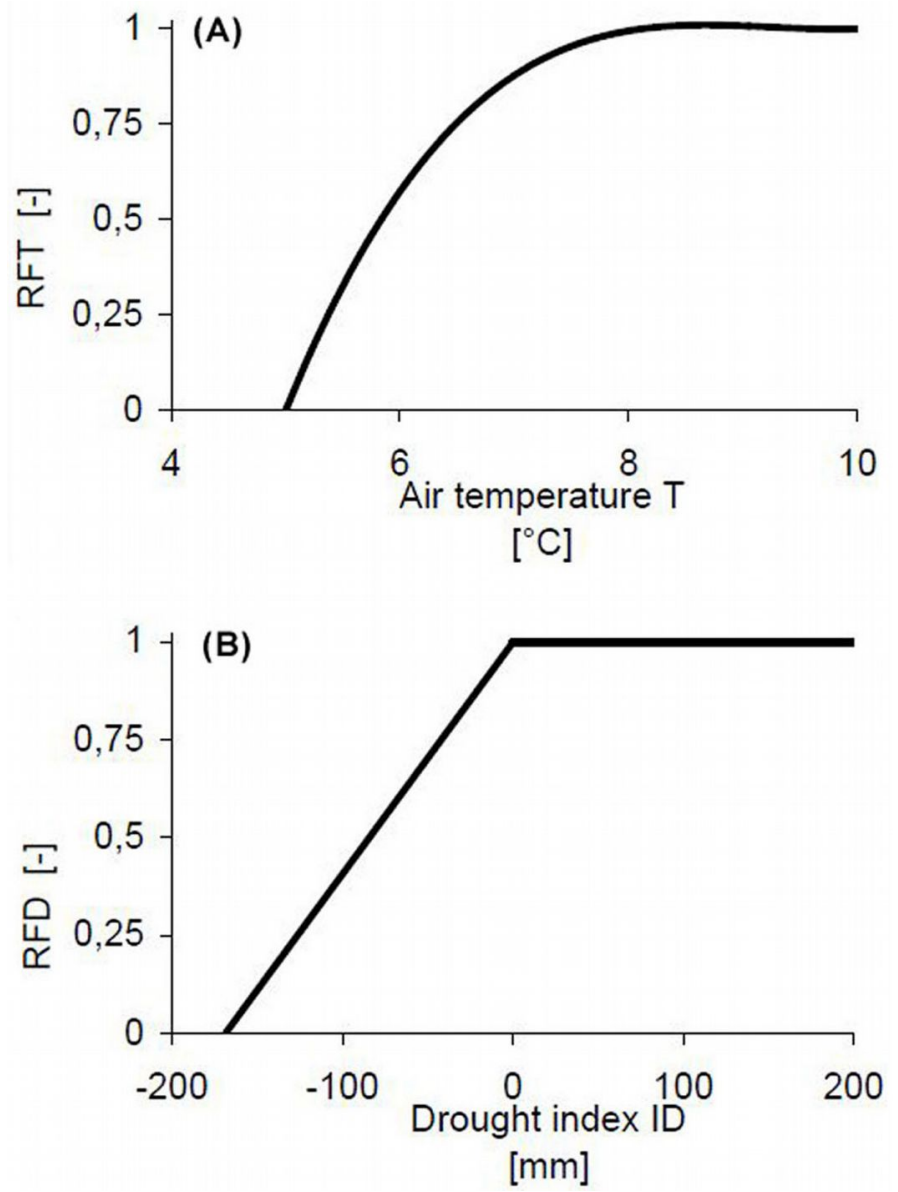

Fig. 3 - Response functions for (A) low mean annual air temperatures (temperature reduction factor $\left.R F_{\mathrm{T}}=0.014 \cdot T^{3}-0.384 \cdot T^{2}+3.538 \cdot T-9.82\right)$ and (B) drought (drought reduction factor $R F_{\mathrm{D}}$; for $I_{\mathrm{D}} \leq 0: R F_{\mathrm{D}}=5.92 \cdot 10^{-4} \cdot I_{\mathrm{D}}+1$; for $\left.I_{\mathrm{D}}>0: R F_{\mathrm{D}}=1\right)$. 
Tab. 2 - Overview of synergy classes for the combination arable land and SRC with regard to the conservation of nature, landscape, and soil.

\begin{tabular}{|c|c|c|}
\hline \multicolumn{2}{|c|}{ Synergy class } & \multirow{2}{*}{ Description } \\
\hline No. & Denotation & \\
\hline 1 & very high synergy & expected synergy effects \\
\hline 2 & high synergy & expected synergy effects but less than in class 1 \\
\hline 3 & verify synergy & $\begin{array}{l}\text { specific evaluation may reveal either a "synergy" or "no } \\
\text { synergy" }\end{array}$ \\
\hline 4 & No synergy - risk & $\begin{array}{l}\text { no synergy effects expected; cultivation of SRC poses a } \\
\text { risk }\end{array}$ \\
\hline 5 & No synergy - exclusion & $\begin{array}{l}\text { cultivation of SRC poses a high risk to nature and the } \\
\text { landscape }\end{array}$ \\
\hline 0 & $\begin{array}{l}\text { neutral - neither synergy } \\
\text { nor risk }\end{array}$ & neutral area; neither synergy effects nor risks expected \\
\hline 9 & not assessed & area not evaluated (all land-use types except arable land) \\
\hline
\end{tabular}

cast poplar biomass yield according to eqn. 3 of $<5 \mathrm{t}_{\mathrm{DW}} \mathrm{ha}^{-1}$ year $^{-1}$, black locust SRC was recommended, with an assumed overall biomass production of $5 \mathrm{t}_{\mathrm{DW}} \mathrm{ha}^{-1}$ year $^{-1}$.

Assessment of possible synergies with nature conservation, landscape and soil protection

Data, legal framework, data processing

A fairly good data foundation on features pertaining to soil protection, land-use distribution and nature conservation exists for Saxony. The data used for the analysis and evaluation of specific areas in this study was provided by the Saxon State Office for Environment, Agriculture, and Geology (LfULG). In most cases it was possible to use pre-processed spatial data:

- digital maps of biotope types and land use types derived from color infrared orthophotos (status: 2005);

- digital soil maps 1:200 000 and 1:25 000;

- digital maps of the vulnerability of soils to erosion by water and wind (for more details, see Feldwisch et al. 2007);

- digital terrain model (grid width: $20 \mathrm{~m}$ );

- digital maps of protected areas according to various nature conservation regulations;

- digital maps of biotopes valuable for nature conservation, including all legally protected biotopes (status: 2009);

- red lists of threatened species and maps detailing the occurrence of selected threatened species.

Some legal regulations also served to de- fine the specific protection status of certain areas:

- Habitats Directive (EC 1992) and Birds Directive of the European Union (EC 1979);

- Saxony Nature Conservation Act (SächsNatSchG 2010) and Saxony Water Act (SächsWG 2010);

- EC cross compliance regulations in agriculture (EC 2003).

The assessment of the risk of erosion by water followed the empirical model provided by the Universal Soil Loss Equation (USLE) developed by Wischmeier \& Smith (1978) and adapted for natural conditions in Germany (Schwertmann et al. 1990 - eqn. 4):

$$
A=R \cdot K \cdot L \cdot S \cdot C \cdot P
$$

where $A$ is the long term average soil loss [ $\mathrm{t}$ $\mathrm{ha}^{-1}$ year $\left.^{-1}\right], R$ is the rainfall erosivity index $\left[\mathrm{N} \mathrm{h}^{-1}\right.$ year-1 $\left.^{-1}\right], K$ is a factor for the soil erodibility [ $\mathrm{th} \mathrm{ha}{ }^{-1} \mathrm{~N}^{-1}$ ] $S$ and $L$ are topographical factors accounting for slope steepness and length [-], $C$ is the plant cover factor [-] and $P$ is a factor that takes account of specific erosion control practices [-].

The interpretations of soil data with regard to single and combinations of the USLE factors transcend the minimum standards of the EC's cross compliance regulations (EC 2003). For example, the vulnerability analysis also contains spatial information concerning erosion-prone steep slopes and areas affected by the potential accumulation of surface run-off.

Tab. 3 - Criteria and indicators for the identification of soil protection synergy effects arising from SRC on arable land in the State of Saxony. (a): Areas without data or assessment were classified to synergy class 9; (b): The total area corresponds to the whole of Saxony (1 $845488 \mathrm{ha}$ ). The value given for each criterion is always relative to the total area of Saxony. (c): Includes aspects of natural and cultural history. Assessment of dominant soil forms only. (d): Category includes bogs and swamps, neglected grassland, rocky and dwarf shrub areas, forests, coppice and hedgerows. (e): No data.

\begin{tabular}{|c|c|c|c|c|c|}
\hline Criterion & Indicator & Classes & $\begin{array}{l}\text { Synergy } \\
\text { class }^{\mathrm{a}}\end{array}$ & $\begin{array}{c}\text { Area } \\
{[\text { ha] }}\end{array}$ & $\begin{array}{c}\text { Proportion } \\
\text { of total } \\
\text { area }^{b}[\%]\end{array}$ \\
\hline \multirow[t]{2}{*}{$\begin{array}{l}\text { Risk of erosion through accumulation of } \\
\text { surface run-off (Thalweg erosion) }\end{array}$} & \multirow[t]{2}{*}{$\begin{array}{l}\text { soil loss \& } \\
\text { catchment size }\end{array}$} & $\begin{array}{l}<15 \mathrm{t} \mathrm{ha}^{-1} \text { and }<2 \text { ha or } \\
\text { n.d. }\end{array}$ & $0 ; 9$ & 1802500 & 97.7 \\
\hline & & $\geq 15 \mathrm{t} \mathrm{ha}^{-1}$ and $\geq 2 \mathrm{ha}$ & 1 & 42908 & 2.3 \\
\hline \multirow{3}{*}{$\begin{array}{l}\text { Prone to water erosion }(K \cdot R \cdot L \cdot S) \\
\text { (sheet and rill erosion) }\end{array}$} & \multirow[t]{3}{*}{ Soil Loss } & $<15 \mathrm{t} \mathrm{ha}^{-1}$ or n.d. ${ }^{\mathrm{e}}$ & $0 ; 9$ & 1369861 & 74.2 \\
\hline & & $15-<30 \mathrm{t} \mathrm{ha}^{-1}$ & 2 & 193888 & 10.5 \\
\hline & & $\geq 30 \mathrm{t} \mathrm{ha}^{-1}$ & 1 & 281739 & 15.3 \\
\hline \multirow{2}{*}{$\begin{array}{l}\text { Particularly susceptible to erosion; } \\
\text { short but steep slopes (sheet and rill erosion) }\end{array}$} & \multirow{2}{*}{ factor $K \cdot S$} & $<0.9$ or $n$. d. $^{\mathrm{e}}$ & $0 ; 9$ & 1771993 & 96 \\
\hline & & $\geq 0.9$ & 1 & 73496 & 4 \\
\hline \multirow[t]{3}{*}{ Prone to wind erosion (LfULG 2007) } & \multirow{3}{*}{$\begin{array}{l}\text { degree of potential } \\
\text { danger }\end{array}$} & none to low or n.d. ${ }^{\mathrm{e}}$ & $0 ; 9$ & 1498391 & 75 \\
\hline & & medium & 2 & 183379 & 9.9 \\
\hline & & high to extremely high & 1 & 163719 & 8.9 \\
\hline \multirow[t]{2}{*}{ Wetlands (LfULG 2007) } & \multirow[t]{2}{*}{ degree of waterlogging } & none to medium or n.d. ${ }^{\mathrm{e}}$ & $0 ; 9$ & 1543863 & 78.3 \\
\hline & & high to extremely high & 4 & 301625 & 16.3 \\
\hline \multirow[t]{2}{*}{ Soils worth protecting (LfULG 2007) } & \multirow{2}{*}{$\begin{array}{l}\text { Potential for } \\
\text { development of biotopes }\end{array}$} & none to low or n.d. ${ }^{\mathrm{e}}$ & $0 ; 9$ & 1321056 & 71.6 \\
\hline & & high to very high & 3 & 524432 & 28.4 \\
\hline \multirow{5}{*}{$\begin{array}{l}\text { Current land use according to the } \\
\text { main classes contained on the } \\
\text { digital land-use maps }\end{array}$} & \multirow[t]{5}{*}{ land-use type } & diverse land uses $^{\mathrm{d}}$ & 5 & 559301 & 30.3 \\
\hline & & grassland & 4 & 306848 & 16.6 \\
\hline & & arable land & 1 & 713439 & 38.7 \\
\hline & & water bodies & 0 & 40134 & 2.2 \\
\hline & & settlement, infrastructure & 9 & 225766 & 12.2 \\
\hline
\end{tabular}


A simplified assessment of the risk of erosion by wind is based on an evaluation of the soil texture, the soil organic matter content in the upper soil, the mean annual wind speed at a height of $10 \mathrm{~m}$, the crops cultivated and the crop rotation, and the height of and distance to wind breaks (LfULG 2007, Deumlich et al. 2006). All of the data and additional information were processed in a geographic information system (GIS).

\section{Definition of synergy classes}

The effects of SRC cultivation on nature, landscape and soil protection may range from positive to negative, or they may be neutral. Therefore, a classification scheme was developed including seven different categories of synergy (Tab. 2). We used a method that included objective and subjective elements within a GIS, known as a spatial expert system (Malcewski 2004).

Several stakeholders from the Saxon State Office for Environment, Agriculture, and Geology, scientists and independent consulting engineers dealing with ecosystem services were involved in the evaluation procedure. Their expert knowledge with regard to landscape ecology, nature and landscape conservation, soil protection, surface water quality, species protection, agricultural management, and biomass production was structured during workshops and personal communication. Furthermore, experts on state subsidies in support of landscape protection were also included. The goal of this procedure was to define indicators facilitating a final categorization of site types according to the classification presented in Tab. 2 .

\section{Results}

\section{Site-based estimation of biomass production potential}

The site-based potential for biomass production was estimated for arable land only An application of the biomass model for other land-use types was ruled out due to the expected risk of negative impacts of biomass production in terms of soil protection (see Tab. 3). Roughly 617400 ha, or $88 \%$ of the arable land of Saxony, are suitable for poplar $\mathrm{SRC}$, with a mean biomass production potential of $12 \mathrm{t}_{\mathrm{DW}}$ ha $^{-1}$ year $^{-1}( \pm 3$, standard de-

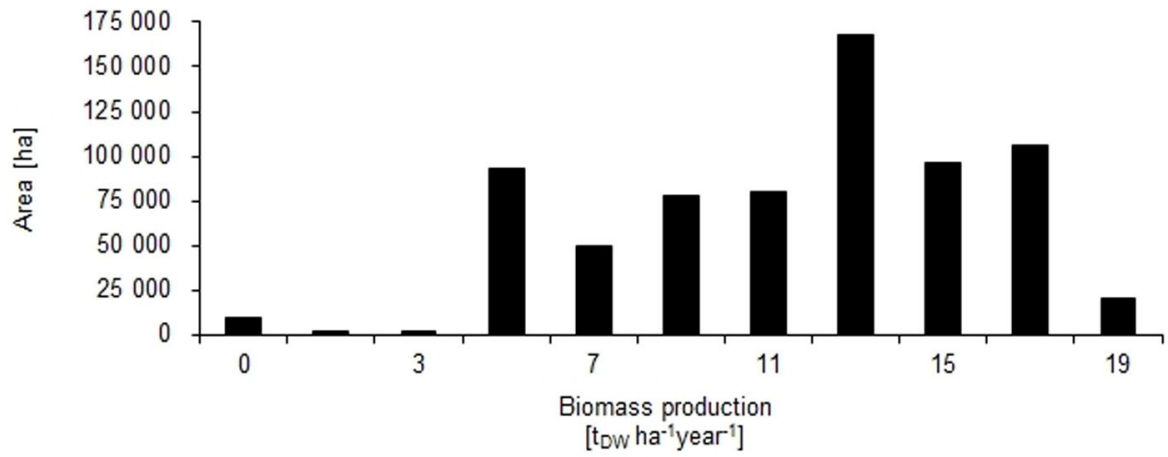

Fig. 4 - Potential surface area and site-based biomass production in SRC on arable land in the State of Saxony. The species considered are poplar, alder, and black locust.

viation). A total of 82900 ha, or $12 \%$ of total arable land in Saxony, were deemed to be suited to alder cultivation, with a mean forecast yield of $4 \mathrm{t}_{\mathrm{DW}} \mathrm{ha}^{-1}$ year-1. The potential area of SRC with black locust was 3400 ha $(<1 \%$ of the total arable land $)$, with an assumed biomass production potential of $5 \mathrm{t}_{\mathrm{DW}}$ $\mathrm{ha}^{-1}$ year $^{-1}$. The distribution of the arable area according to different biomass production classes is illustrated in Fig. 4.

\section{Soil protection}

The assessment of synergy effects for soil protection on arable sites with SRC was based on seven criteria (Tab. 3), which were applied to the total area of Saxony (1 845488 ha). The main evaluation results are presented in Tab. 3. More than $25 \%$ of the state's total area, for example, is prone to water erosion. Therefore, perennial crops like trees managed as SRC would have high and very high synergy effects in terms of reducing the erosion potential.

\section{Nature conservation}

The discussion process involving nature conservation stakeholders resulted in the application of four synergy classes: 0 (neutral), 1 (very high synergy - Tab. 4), 3 (verify synergy - Tab. 5) and 5 (exclusion - Tab. 6). Areas deemed to have a very high synergy amount to $26 \%$ of Saxony's total arable land area and mainly are located in the sparsely wooded regions in central and northern Saxony (Tab. 4). The establishment of a bio- tope network may also prove beneficial (very high synergy), if SRC with edges comprising native tree and shrub species and with a rotation period $\geq 10$ years. A visual evaluation was based on merged soil protection and nature conservation data sets (results not shown).

For an area $>272000$ ha, or $38 \%$ of Saxony's arable land, an additional, more detailed evaluation (synergy class 3 ) is needed in order to come to a final synergy classification (Tab. 5). Special knowledge of the landscape characteristics and the specific protection goals is necessary. To achieve this, an assessment should be made on a local scale in cooperation with stakeholders from the district or even municipality level.

Areas not suitable to SRC plantations (Tab. 5 ) consist of sites that are top priority for nature conservation goals, as defined by law. Overall, $2.3 \%$ of Saxony's total arable land, or 16363 ha, was grouped in synergy class 5. Finally, 231669 ha respectively $33 \%$ of the arable land were assessed to be neutral if planted with SRC. That means neither synergy nor risk is expected on these sites.

\section{Synthesis}

The results of the assessment of the soil protection and nature conservation features were merged within a GIS. Where more than one synergy class was found for a particular area on the basis of the different criteria, the inferior synergy class was prioritized.

The arable land deemed to have high and

Tab. 4 - Areas characterised by very high synergy if planted with SRC (synergy class 1: "very high”). (a): Less areas of synergy classes 3 and 5.

\begin{tabular}{|c|c|c|c|c|}
\hline $\begin{array}{l}\text { Synergy class } 1 \\
\text { very high synergy }\end{array}$ & Criterion & $\begin{array}{l}\text { Total area in } \\
\text { Saxony [ha] }\end{array}$ & $\begin{array}{l}\text { Arable land }^{\mathrm{a}} \\
{[\mathrm{ha}]}\end{array}$ & $\begin{array}{c}\text { Proportion of } \\
\text { total arable } \\
\text { land [\%] }\end{array}$ \\
\hline Sparsely wooded regions & $\begin{array}{l}\text { Regions where Saxony's regional planning body recom- } \\
\text { mends an increase in the forest cover }\end{array}$ & 472478 & 180686 & 25.7 \\
\hline Buffer along water edges & $\begin{array}{l}\text { After a } 10 \mathrm{~m} \text { strip to allow for close to nature development } \\
\text { (see Tab. 5) a } 20 \mathrm{~m} \text { strip of SRC should follow (vegetative } \\
\text { filter strip) }\end{array}$ & 104667 & 6509 & 0.9 \\
\hline \multicolumn{2}{|c|}{ Total area, adjusted by overlapping areas within this synergy class } & 555341 & 184045 & 26.1 \\
\hline
\end{tabular}


Tab. 5 - Areas requiring further evaluation and the consideration of specific protection goals; assessment on a regional and local scale (syn ergy class 3: "verify synergy"). (a): Less areas of synergy class 5. (b): Search area with current and potential occurrence of rare or threatened wild plants of arable land.

\begin{tabular}{|c|c|c|c|c|}
\hline $\begin{array}{l}\text { Synergy class } 3 \\
\text { verify synergy }\end{array}$ & Criterion & $\begin{array}{l}\text { Total area in } \\
\text { Saxony [ha] }\end{array}$ & $\begin{array}{l}\text { Arable land }^{\mathrm{a}} \\
\qquad[\mathrm{ha}]\end{array}$ & $\begin{array}{c}\text { Proportion of } \\
\text { total arable } \\
\text { land }^{\mathrm{a}}[\%]\end{array}$ \\
\hline $\begin{array}{l}\text { Landscape conservation } \\
\text { area (protected landscape } \\
\text { according to IUCN } \\
\text { classification) }\end{array}$ & $\begin{array}{l}\text { Damage and impairment of protection goals defined in } \\
\text { management plans to be avoided; responsibility of } \\
\text { district administration }\end{array}$ & 557018 & 173020 & 24.6 \\
\hline $\begin{array}{l}\text { Sites of community impor- } \\
\text { tance (SCI) according to } \\
\text { EU Habitats Directive }\end{array}$ & $\begin{array}{l}\text { Damage and impairment of conservation goals of SCIs } \\
\text { to be avoided }\end{array}$ & 168667 & 6397 & 0.9 \\
\hline $\begin{array}{l}\text { Special protected area } \\
\text { (SPA) according to EU } \\
\text { Birds Directive }\end{array}$ & $\begin{array}{l}\text { Damage and impairment to conservation goals of SPAs } \\
\text { to be avoided }\end{array}$ & 248965 & 45791 & 6.5 \\
\hline $\begin{array}{l}\text { Biosphere reserve: deve- } \\
\text { lopment zone (or transi- } \\
\text { tion area according to } \\
\text { UNESCO definition) }\end{array}$ & $\begin{array}{l}\text { Damage and impairment to specific management goals } \\
\text { of development zones to be avoided }\end{array}$ & 16952 & 4802 & 0.7 \\
\hline $\begin{array}{l}\text { Nature park (protected } \\
\text { landscape according to } \\
\text { IUCN classification) }\end{array}$ & $\begin{array}{l}\text { Impairment of goals defined in management plans to be } \\
\text { avoided (e.g., recreational function); responsibility of } \\
\text { district administration }\end{array}$ & 198796 & 30761 & 4.4 \\
\hline $\begin{array}{l}\text { Field margins, sites with } \\
\text { rare or threatened wild } \\
\text { herb species }\end{array}$ & $\begin{array}{l}\text { Occurrence of rare or threatened (critically endangered, } \\
\text { endangered or vulnerable) plant species }\end{array}$ & 143744 & 84550 & $12.0^{\mathrm{b}}$ \\
\hline $\begin{array}{l}\text { Areas recommended for } \\
\text { biomass production with } \\
\text { black locust (Robinia } \\
\text { pseudoacacia) }\end{array}$ & $\begin{array}{l}\text { Damage to protected biotopes to be avoided by } \\
\text { ensuring a minimum distance of } 500 \mathrm{~m} \text { to black locust } \\
\text { SRC }\end{array}$ & 3408 & 3391 & 0.5 \\
\hline $\begin{array}{l}\text { Buffer around high prio- } \\
\text { rity protected areas }\end{array}$ & $\begin{array}{l}\text { Damage to protected objects in top priority protected ar- } \\
\text { eas (see Tab. } 5 \text {; e.g., shading of margins rich in species) } \\
\text { to be avoided by installing a buffer of } 20 \mathrm{~m}\end{array}$ & 3337 & 699 & 0.1 \\
\hline $\begin{array}{l}\text { Habitats of rare and threat- } \\
\text { ened or legally } \\
\text { protected wild species }\end{array}$ & $\begin{array}{l}\text { Damage to be avoided; cultivation of SRC in strips may } \\
\text { be an alternative to SRC in closed blocks. } \\
\text { Further evaluation needed }\end{array}$ & $\begin{array}{l}\text { no specific area } \\
\text { for evaluation, } \\
\text { data incomplete }\end{array}$ & - & - \\
\hline \multicolumn{2}{|c|}{ Total area, adjusted by overlapping areas within this synergy class } & 913715 & 272074 & 38.6 \\
\hline
\end{tabular}

Tab. 6 - Areas with no nature conservation synergies (synergy class 5: “exclusion”). (a): SächsNatSchG (2010); (b): SächsWG (2010).

\begin{tabular}{|c|c|c|c|c|}
\hline $\begin{array}{l}\text { Synergy class } 5 \\
\text { no synergy - exclusion }\end{array}$ & Criterion & $\begin{array}{l}\text { Total area in } \\
\text { Saxony [ha] }\end{array}$ & $\begin{array}{l}\text { Arable land } \\
\text { [ha] }\end{array}$ & $\begin{array}{l}\text { Proportion of } \\
\text { total arable } \\
\text { land }[\%]\end{array}$ \\
\hline National park; entire area & $\begin{array}{l}\text { Long term development and protection of natural } \\
\text { self-regulation (processes without human interference) } \\
\text { have top priority }\end{array}$ & 9354 & 180 & $<0.1$ \\
\hline $\begin{array}{l}\text { Biosphere reserve; core } \\
\text { area and buffer zone }\end{array}$ & $\begin{array}{l}\text { Protection goals have top priority as core areas (strict na- } \\
\text { ture reserve) and buffer zones (habitat and species man- } \\
\text { agement areas) are nature reserves by law }{ }^{\mathrm{a}}\end{array}$ & 13165 & 465 & $<0.1$ \\
\hline $\begin{array}{l}\text { Nature reserve (IUCN } \\
\text { categories: strict nature } \\
\text { reserve and habitat/ } \\
\text { species management area) }\end{array}$ & Protection goals have top priority by law ${ }^{\mathrm{a}}$ & 51861 & 1180 & 0.2 \\
\hline $\begin{array}{l}\text { Natural monuments } \\
\text { (areas up to } 5 \text { ha) }\end{array}$ & Protection goals have top priority by law ${ }^{\mathrm{a}}$ & $\begin{array}{r}6500 \\
\text { (approx.) }\end{array}$ & $\begin{array}{r}250 \\
\text { (approx.) }\end{array}$ & $<0.1$ \\
\hline $\begin{array}{l}\text { Worth protecting biotopes } \\
\text { (selective biotope } \\
\text { mapping) }\end{array}$ & $\begin{array}{l}\text { Protection goals have high priority, legally designated } \\
\text { protected biotopes are included. Damage forbidden }\end{array}$ & 97724 & 1649 & 0.2 \\
\hline Water edges & $\begin{array}{l}\text { A strip of } 10 \mathrm{~m} \text { alongside waterway should be allowed } \\
\text { to develop in a way that is close to nature }\end{array}$ & 56483 & 4675 & 0.7 \\
\hline $\begin{array}{l}\text { European hamster } \\
\text { (C. cricetus) habitats }\end{array}$ & $\begin{array}{l}\text { Protected according to annex IV of the Habitats Directive } \\
\text { (EC 1992). Habitat must be preserved. Cultivation of } \\
\text { SRC in strips may be possible. Further evaluation } \\
\text { needed. }\end{array}$ & 10401 & 8727 & 1.2 \\
\hline Total & & 193704 & 16363 & 2.3 \\
\hline
\end{tabular}


Fig. 5 - Site-based biomass production potential of SRC plantations on arable land deemed to have either a high or a very high synergy effect with respect to soil protection and/or nature conservation within the State of Saxony (Germany). Boundaries are natural landscape units ("Makrochoren").
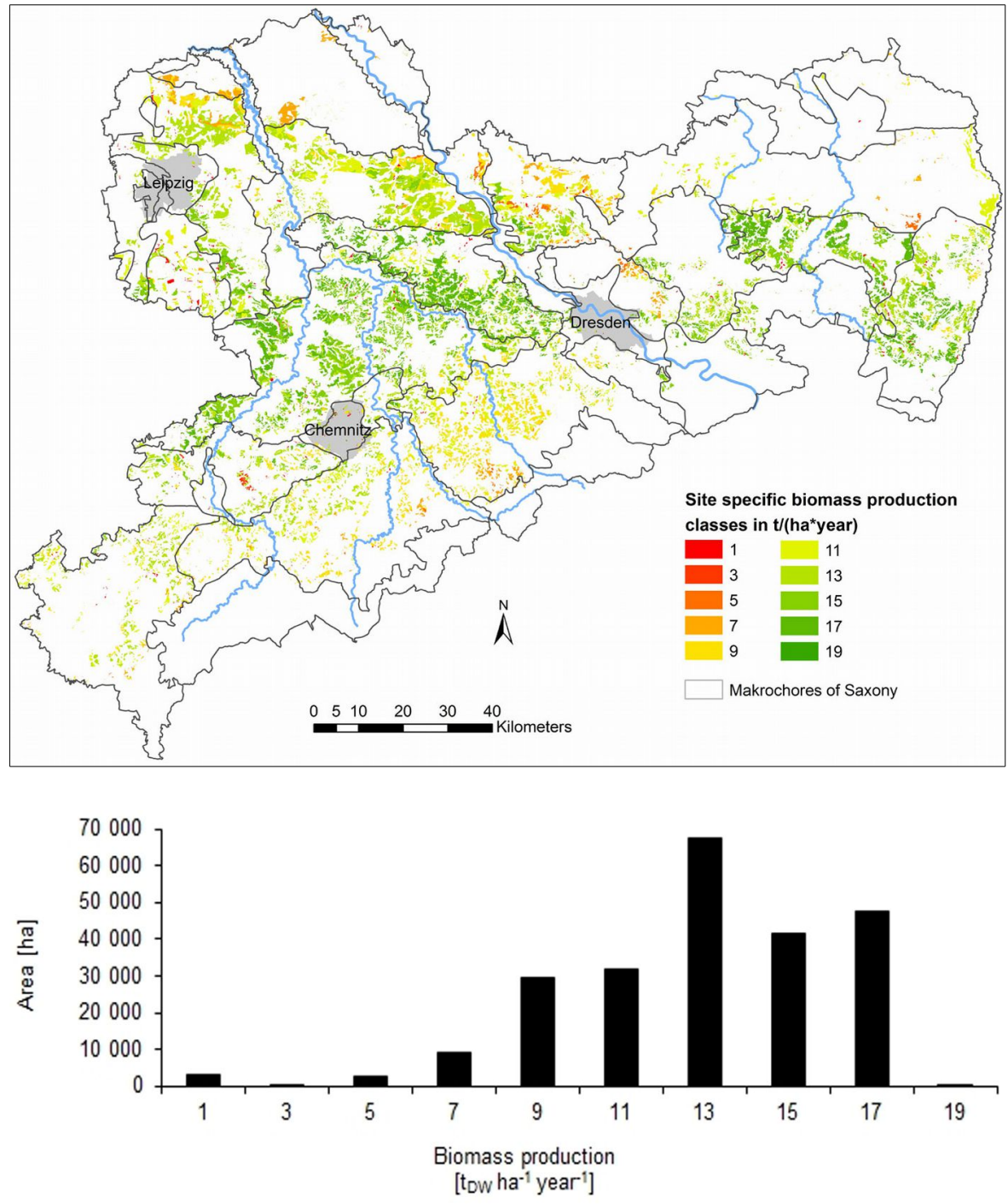

Fig. 6 - Site-based biomass production of SRC plantations on areas identified as having a high or very high synergy effect with respect to soil protection and/or nature conservation goals.

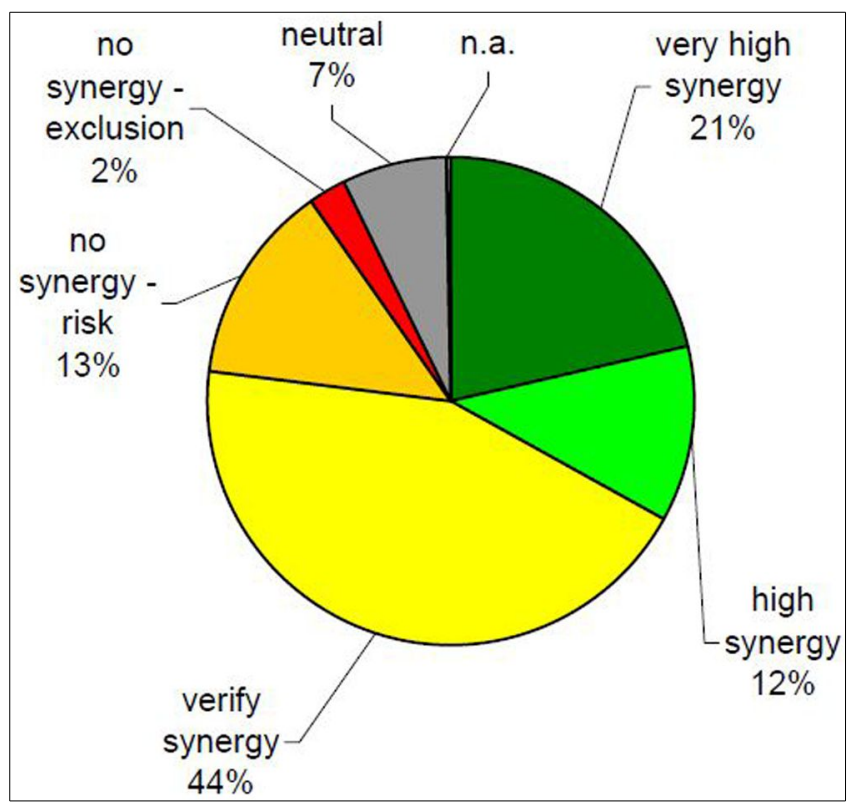
synergy classes with respect to SRC on arable land after all soil protection and nature conservation assessment criteria are merged. (n.a.): not assessed.
Fig. 7 - Distribution of a very high synergy effect; 83555 ha (12\%) high synergy; 313718 ha (45\%) need further evaluation; 95087 ha (13\%) have no synergy but potentially pose a risk; 16610 ha $(2 \%)$ have no synergy and should be completely excluded from SRC; the effect of SRC is deemed neutral on 50932 ha (7\%) and 1387 ha $(<1 \%)$ were not assessed (see relative proportions in Fig. 7).

\section{Discussion}

The range of the site-based biomass production estimates attained in this study compares with independent results from demon- 
stration plots in Germany (Hoffmann \& Weih 2005). They found average poplar SRC yields of 6 to $18 \mathrm{t}_{\mathrm{DW}} \mathrm{ha}^{-1}$ year-1 depending on soil and climatic conditions. However, it should be noted that available information regarding biomass yields in Saxony has been collated from experimental and demonstration plots. This often results in a bias in the findings in favor of higher yields than can be achieved under actual management conditions. At the same time, ongoing improvements to management technologies will counterbalance these possibly too optimistic biomass production estimates (MolaYudego 2011).

The assessment of the impact of SRC on areas with regard to soil protection excluded land presently used as grassland (mainly pasture). The main concerns here were a distinct loss of soil organic carbon, leaching of nitrate into the groundwater, and the release of carbon dioxide into the atmosphere due to increased mineralization following conversion from grassland to SRC (Don et al. 2009, Ciais et al. 2010). However, a land use change from grassland to SRC does not necessarily imply high losses of soil organic carbon (Don et al. 2012). Hence, the total green house gas balance will be highly dependent on type and management of grassland, cultivation practice, in particular ploughing as well as the lifetime and the re-cultivation technique after abandonment of SRC plantations (Don et al. 2012).

The scale of the study design was the regional level. This information may serve for a rational allocation of subsidies to encourage SRC and maximize synergy effects according to the site conditions in different regions. However, the relatively large area of synergy class 3 "verify synergy" needs to be refined and tested at a lower (farm, district) level. Detailed knowledge of objects of nature and landscape protection, and existing management plans for protected areas under the responsibility of district authorities should be incorporated in an ongoing and refined appraisal process. For better incorporation of potential biotope networks, however, a more detailed assessment according to the type of biotope and other overlapping criteria is necessary. A key problem for each assessment remains the definition of criteria and appropriate indicators. In particular, indicators for the assessment of the effects of SRC on biodiversity still rely on existing data sets not specific to SRC. It would appear to be necessary to monitor the actual ef fects on biodiversity of newly established SRC on arable land for the development and adaptation of appropriate indicators.

Another planning approach, the sustainability appraisal framework (SAF), also includes the economic and social implications of a land-use change due to increased biomass production (Haughton et al. 2009).
These authors adopted an approach in which environmental and physical constraints are mapped with the identification of stakeholder aspirations. The abundance of butterflies was found to be an appropriate indicator for the assessment of the biodiversity of different biomass crop systems. However, which mechanisms are suited to implementing the identified synergy effects in practice remains open. Fohrer et al. (2002) combined the agrieconomic model ProLand, for the generation of spatially distributed land-use scenarios, the grid based YELL model, to simulate the distribution of breeding habitats of key species, and finally the hydrological model SWAT, to assess changes in land use on hydrologic ecosystem services. With this combined model framework, Fohrer et al. (2002) demonstrated multidimensional trade-offs. This approach may represent an important information base for decision makers. Nevertheless, the authors highlighted that the uncertainty associated with the model is high and needs to be addressed. The priority areas identified for SRC in this study may also serve as an input for a spatially explicit modeling of scenarios and for an integrated assessment of hydrologic ecosystem services, like flood protection, water quality or groundwater recharge (Brauman et al. 2007) at the catchment scale. Such efforts are currently being undertaken as part of the joint research project AgroForNet (2011, TU Dresden 2011).

\section{Conclusions}

The conceptual framework for planning SRC and the incorporation of nature conservation and soil protection goals presented in this paper yields spatially explicit information concerning priority areas and the sitespecific biomass production potential at the regional scale. The results may serve as important basic information supporting the allocation of subsidies for a joint improvement of biomass production, soil protection, and nature conservation.

However, the approach for yield estimation is limited to agricultural site conditions. An equivalent evaluation for grassland (mainly pasture) is lacking as yet but should be carried out. Further research is needed to determine whether advanced SRC cultivation techniques like direct planting, planting in strips, and the avoidance of deep ploughing when the plantation is established on grassland sites may prevent excess mineralization of soil organic matter. Nevertheless, it is clear that grassland characterized by a low level of management intensity is often of high nature conservation value and should not converted into SRC.

To prevent wind erosion, it may be sufficient to plant fast growing tree species in strips rather than blocks. This would mean that smaller areas are needed to maximize synergy effects. The optimal land-use type in susceptible regions will, therefore, more closely resemble an agroforestry system than a conventional SRC plantation.

Further development of the framework should also include other ecosystem services related to soil and water resources (e.g., carbon sequestration, flood protection, groundwater recharge). Another focus should be the refinement of the planning tool at the local (farm, district) scale. Stakeholders must be involved at each step in order to make the greatest use of existing knowledge, particularly information on biodiversity, and to ensure broad acceptance of planning outcomes. A gap in the existing knowledge was identified with respect to the uncertain soil ecological impact of advanced SRC establishment techniques on sites which hitherto have been used as grassland. Finally, indicators for better assessment of biodiversity in SRC should be developed on the basis of current monitoring programmes.

\section{Acknowledgements}

The study was funded by the Saxon State Ministry of the Environment and Agriculture (SMUL). We acknowledge the valuable comments of two anonymous reviewers.

\section{References}

Ad-hoc-AG Boden (2005). Bodenkundliche Kartieranleitung [Soil mapping] $\left(5^{\text {th }}\right.$ edn). Schweitzerbartsche Verlagsbuchhandlung, Stuttgart, Germany, pp. 438. [in German]

AgroForNet (2011). Nachhaltige Entwicklung ländlicher Regionen durch die Vernetzung von Produzenten und Verwertern von Dendromasse für die enrgetische Nutzung [Sustainable development of rural areas through the linking-up of producers and consumers of wood fuel]. Web site. [in German] [online] URL: http://www.energieholz- portal.de/89-0-Abstract.html

Ali W (2009). Modelling of biomass production potential of poplar in short rotation plantations on agricultural lands of Saxony. PhD thesis, Faculty of Forest, Geo and Hydro Sciences, TU Dresden, Germany, pp. 130.

Berndes G, Hansson J (2007). Bioenergy expansion in the EU: cost-effective climate change mitigation, employment creation and reduced dependency on imported fuels. Energy Policy 35: 5965-5979 - doi: 10.1016/j.enpol.2007.08.003

Böhm C, Quinkenstein A Freese D, Hüttl R (2009). SRC at reclamation sites of Lower Lusatia - Growth development of four-year-old black locust. AFZ/DerWald 64: 532-533. [in German] Brauman KA, Daily GC, Duarte TK, Mooney HA (2007). The nature and value of ecosystem services: an overview highlighting hydrologic services. Annual Review of Environment and Resources 32 (1): 67-98. - doi: 10.1146/annurev.energy.32.031306.102758

Ciais P, Soussana JF, Vuichard N, Luyssaert S, Don A, Janssens IA, Piao SL, Dechow R, Lathière J, Maignan F, Wattenbach $\mathrm{M}$, Smith $\mathrm{P}$, Am- 
mann C, Freibauer A, Schulze ED (2010). The greenhouse gas balance of European grasslands. Biogeosciences Discussions 7 (4): 5997-6050. doi: 10.5194/bgd-7-5997-2010

Daily GC, Alexander S, Ehrlich PR, Goulder L, Lubchenco J, Matson PA, Mooney HA, Postel S, Schneider SH, Tilman D, Woodwell GM (1997). Ecosystem services: benefits supplied to human societies by natural ecosystems. Issues in Ecology 2: 1-16. [online] URL: http://www.wvhighlands.org/VoicePast/VoiceJun99/EcoServices.JS. June99Voice.txt.htm

Deumlich D, Funk R, Frielinghaus M, Schmidt WA, Nitzsche O (2006). Basics of effective erosion control in German agriculture. Journal of Plant Nutrition and Soil Science 169: 370-381. doi: 10.1002/jpln.200621983

deWit M, Faaij A (2010). European biomass resource potential and costs. Biomass and Bioenergy 34: 188-202 - doi: 10.1016/j.biombioe.20 09.07.011

Don A, Rebmann C, Kolle O, Scherer-Lorenzen M, Schulze ED (2009). Impact of afforestationassociated management changes on the carbon balance of grassland. Global Change Biology 15: 1990-2000 - doi: 10.1111/j.1365 2486.2009.01873.x

Don A, Osborne B, Hastings A, Skiba U, Carter MS, Drewer J, Flessa H, Freibauer A, Hyvönen N, Jones MB, Lanigan GJ, Mander Ü, Monti A, Djomo SN, Valentine J, Walter K, ZegadaLizarazu W, Zenone T (2012). Land-use change to bioenergy production in Eusrope: implications for the greenhouse gas balance and soil carbon. GCB Bioenergy 4: 372-391. - doi: 10.1111/j. 1757-1707.2011.01116.x

EC (1979). Council Directive 79/409/EEC on the Conservation of Wild Birds. European Council, Brussels, Belgium, pp. 18. [online] URL: http://eur-lex.europa.eu/search.html?type=expert \&qid $=1398084827346$

EC (1992). Council Directive 92/43/EEC on the Conservation of Natural Habitats and of Wild Fauna and Flora. European Council, Brussels, Belgium. [online] URL: http://eur-lex.europa. eu/legal-content/EN/TXT/?uri=CELEX:31992L0 043

EC (2003). Council Regulation (EC) No 1782/2003 of 29 September 2003 establishing common rules for direct support schemes under the common agricultural policy and establishing certain support schemes for farmers and amending Regulations (EEC). European Council, Brussels, Belgium, pp. 69. [online] URL: http://faolex.fao.org/docs/pdf/eur40622.pdf

EC (2009). Directive 2009/28/EC of the European Parliament and the Council on the promotion of the use of energy from renewable sources. Official Journal of the European Union L 140, 5 June 2009, pp. 16-47. [online] URL: http://faolex.fao.org/docs/pdf/eur88009.pdf

Feldwisch N, Friedrich C, Schlumprecht H (2007). Arbeitshilfe - Bodenschutzfachlicher Beitrag zur Entwicklung von Umsetzungsstrategien und Umsetzungsinstrumenten für eine umweltverträgliche Landnutzung in Natura2000-
Gebieten [Working material - Contribution to soil protection for the development of strategies and instruments for the implementation of green land use in Natura 2000 Habitats]. Research Report LfuLG, Dresden, Germany, pp. 97. [in German]

Fohrer N, Möller D, Steiner N (2002). An interdisciplinary modelling approach to evaluate the effects of land use change. Physics and Chemistry of the Earth, Parts A/B/C 27: 655-662 doi: 10.1016/S1474-7065(02)00050-5

Glaser T, Schmidt PA (2010). Impacts of SRC on phytodiversity (in German). In: "AGROOWOOD Kurzumtriebsplantagen in Deutschland und europäische Perspektiven" (Bemmann A, Knust C eds). Weißensee Verlag, Berlin, Germany, pp. 153-160

Haughton AJ, Bond AJ, et al. (2009). A novel, integrated approach to assessing social, economic and environmental implications of changing rural land-use: a case study of perennial biomass crops. Journal of Applied Ecology 46: 315-322 doi: 10.1111/j.1365-2664.2009.01623.x

Hoffmann D, Weih M (2005). Limitations and improvement of the potential utilisation of woody biomass for energy derived from short rotation woody crops in Sweden and Germany. Biomass and Bioenergy 28: 267-279 - doi: 10.1016/j.biombioe. 2004.08.018

Hellebrand H, Strähle M, Scholz V, Kern J (2010). Soil carbon, soil nitrate, and soil emissions of nitrous oxide during cultivation of energy crops. Nutrient Cycling in Agroecosystems 87: 175-186 - doi: 10.1007/s10705-009-9326-z Lamersdorf N, Petzold R, Schwärzel K, Feger KH, Köstner B, Moderow U, Bernhofer C, Knust C (2010). Soil ecological aspects of SRC. In: "AGROWOOD - Kurzumtriebsplantagen in Deutschland und europäische Perspektiven" (Bemmann A, Knust C eds). Weißensee-Verlag, Berlin, Germany, pp. 170-188. [in German]

LfULG (2007). Bodenatlas des Freistaates Sachsen. Teil 4: Auswertekarten zum Bodenschutz. [Soil Atlas of the Free State of Saxony. Part 4: scorecards for soil conservation]. Saxoprint Dresden, Germany. [DVD]

LfULG (2011). Bodenschätzung [Soil evaluation]. Web site. [in German] [online] URL: http:// www.umwelt.sachsen.de/umwelt/boden/11629.ht $\mathrm{m}$

Lockow KW (1995). Die neue Ertragstafel für Roterle - Modellstruktur und Anwendung in der Forstpraxis [The new yield tables for red alder model structure and application in forestry practice]. Beiträge für Forstwirtschaft und Landschaftsökologie 29: 49-55. [in German]

Makeschin F (1994). Effects of energy forestry on soils. Biomass and Bioenergy 6: 63-79 - doi: 10.1016/0961-9534(94)90086-8

Malcewski J (2004). GIS-based land-use suitability analysis: a critical overview. Progress in Planning 62: 3-65 - doi: 10.1016/j.progress.2003.09. 002

Mola-Yudego B (2011). Trends and productivity improvements from commercial willow plantations in Sweden during the period 1986-2000.
Biomass and Bioenergy 35: 446-453 - doi: 10.1016/j.biombioe.2010.09.004

Peters K, Bilke G, Strohbach B (2007). Yield performance of six-year-old black locust (Robinia pseudoacacia) on four former arable sites of different soil quality in Brandenburg (in German). Archiv f. Forstwesen u. Landschafts.ökol 41: 2628.

Petzold R, Schwärzel K, Feger KH (2011). Transpiration of a hybrid poplar plantation in Saxony (Germany) in response to climate and soil conditions. European Journal of Forest Research 130 (5): 695-706. - doi: 10.1007/s10342-010-0459-z Pretzsch J, Skodawessely C (2010). Socio-economic and ethical aspects of short rotation coppice. In: "AGROWOOD - Kurzumtriebsplantagen in Deutschland und europäische Perspektiven" (Bemmann A, Knust C eds). WeißenseeVerlag, Berlin, Germany, pp. 230-242. [in German]

Röhle H, Böcker L, Feger KH, Petzold R, Wolf H, Ali W (2008). Establishment and expected yield of short-term rotation plantations in Eastern Germany. Schweiz Z Forstwes 159: 133-139. - doi: 10.3188/szf.2008.0133

Rowe RL, Hanley ME, Goulson D, Clarke DJ, Doncaster CP, Taylor G (2011). Potential benefits of commercial willow Short Rotation Coppice (SRC) for farm-scale plant and invertebrate communities in the agri-environment. Biomass and Bioenergy 35 (1): 325-336. - doi: 10.1016/j.biombioe. 2010.08 .046

SABAP (2007). Use of biomass for energy generation - recommendations to policy makers. Expertise of the Scientific Advisory board on Agricultural Policy (SABAP), German Federal Ministry of Food and Agriculture, Web site. [online] URL: http:/www.bmel.de/SharedDocs/Downloa ds/Ministerium/Beiraete/Agrarpolitik/GutachtenWBA.html

SABAP (2010). EU agricultural policy after 2013 - Plea for a new policy for food, agriculture and rural areas. Expert opinion of the Scientific Advisory board on Agricultural Policy (SABAP), German Federal Ministry of Food and Agriculture, Web site. [online] URL: http://www.bmel.de/EN/Ministry/Scientific-Advisory-Boards/ Texte/EU-ag-policy-after-2013.html SächsNatSchG (2010). Saxon Nature Conservation Act. SächsGVB1., pp. 270. [in German] [online] URL: http://www.bundesrecht24.de/

SächsWG (2010). Saxon Water Act. SächsGVB1., pp. 270. [in German] [online] URL: http://www. bundesrecht24.de/

Schmidt-Walter P, Lamersdorf N (2012). Biomass production with willow and poplar short rotation coppices on sensitive areas - The impact on nitrate leaching and groundwater recharge in a drinking water catchment near Hannover, Germany. Bioenergy Research 5 (3): 546-562. - doi: 10.1007/s12155-012-9237-8

Schwanecke W, Kopp D (1996). Forstliche Wuchsgebiete und Wuchsbezirke im Freistaat Sachsen [Forest growth regions and districts in Saxony]. Schriftenreihe der Sächsischen Landesanstalt für Forsten 8, Graupa, Germany, pp. 
191. [in German] [online] URL: http://www.smul.sachsen.de/sbs/download/SR_08_1996.pdf Schwertmann U, Vogel W, Kainz M (1990). Bodenerosion durch Wasser [Soil erosion by water]. Vorhersage des Abtrags und Bewertung von Gegenmaßnahmen. Verlag Eugen Ulmer, Stuttgart, Germany, pp. 64.

Skodawessely C, Glaser T, Pretzsch J, Schmidt PA (2008). Attitudes of farmers and nature con- servation associations to short-rotation coppice (in German). Swiss Forestry Journal 159: 158164 - doi: 10.3188/szf.2008.0158

SMUL (2008). Sachsen im Klimawandel - Eine Analyse [Climate change in Saxony - an analysis]. State Ministry of the Environment and Agriculture, web site. [in German] [online] URL: http://www.umwelt.sachsen.de/umwelt/klima/19 88.htm
TU Dresden (2011). AgroForNet. Web site. [in German] [online] URL: http://www.agrofornet.de

Wischmeier W, Smith D (1978). Predicting rainfall erosion loss: a guide to conservation planning. Agriculture Handbook 537, USDA, Washington, DC, USA, pp. 58. 